\title{
A Democratic Defence of the Court Challenges Program
}

\section{Larissa Kloegman ${ }^{\star}$}

The introduction of the Charter of Rights and Freedoms ${ }^{1}$ has provided many historically disadvantaged groups with an opportunity to have their rights acknowledged in the policy process. Indeed the Charter places a legal obligation upon governments to ensure their legislative efforts respect the rights of historically disadvantaged groups. Some claim, however, that the Charter has produced activist judges who create rights for "special" interest groups rather than defer to Parliament. Others suggest Canada's parliamentary system is not, on its own, favourable to all Canadians, and many groups and individuals are forced to the courts to make their interests and concerns known to government policy makers and legislators. The Court Challenges Program (CCP) was at the centre of this debate. This modest, federally funded initiative contributed to the protection and promotion of Canada's official language minority groups (OLMGs) for almost thirty years, and provided assistance to groups seeking to assert their section 15 Charter rights for almost twenty. The Court Challenges Program served as a last resort for many of Canada's most disadvantaged groups, but the Harper government recently took the position that the CCP was one of several "wasteful programs" not "providing good value for money." Funding for the program was eliminated in 2006, silencing many of Canada's most vulnerable groups.

After a brief look at the history and importance of the Court Challenges Program, this article offers an explanation for its cancellation and a fresh perspective on why it is important to reinstate it. In essence, the Conservative government appears to have adopted the analytical lens of Ted Morton \& Rainer Knopff's "Charter revolution" theory to judge the merits of the program. ${ }^{3}$ Considered in this light, it should not be surprising that the CCP was deemed a nuisance and eliminated. Unfortunately for many groups including OLMGs in Alberta, this means that it is now more difficult for members of disadvantaged groups to hold governments to account for failing to respect their Charter rights in the policy process.

Although a centralization of political power in Canada has been occurring for decades, the current government is the most extreme expression of its concentration in the Prime Minister's Office (PMO). As a result, traditional access points to government are diminishing ever more rapidly, forcing Canadians to use the courts in a last attempt to contribute to policy and legislation. Unfortunately, as litigation is both timely and expensive, only the richest in society can afford to utilize this final resort without a litigation-support program such as the CCP. Indeed, without the program, Canada's most vulnerable groups will continue to be left out in the cold.

\section{What is the Court Challenges Program?}

The Court Challenges Program was created in 1978 by the federal government under Pierre Trudeau to assist language minorities (Francophones living outside Quebec and Anglophones living inside Quebec) wishing to challenge provincial legislation that might violate the Constitution Act, $1867^{4}$ or the Manitoba Act, $1870 .^{5}$

When section 15 of the Charter came into 
effect in 1985, many organizations lobbied the Mulroney government for a program similar to that of the CCP. Rather than create a new program, Minister of Justice John Crosbie expanded the mandate of the Court Challenges Program to include support for litigation efforts under sections 15 and $28^{6}$ of the Charter. Crosbie contracted the Canadian Council on Social Development (CCSD) to administer the program and granted it $\$ 9$ million over five years. ${ }^{8}$ The program was renewed in 1990 with a five-year budget of $\$ 12$ million. Nevertheless, the Mulroney government eliminated the funding for the CCP in 1992. Public outcry caused the cancellation of the CCP to become a major issue and promises of its reinstatement surfaced in the campaigns of both the Liberal and Progressive Conservative parties in the following federal election.

In 1994, the federal government resuscitated the Court Challenges Program of Canada, this time as a nonprofit corporation with a three-year contract worth an annual $\$ 2.75$ million. Since then, the program's funding has been twice renewed, most recently in 2004 when the CCP was guaranteed an annual budget of $\$ 2.85$ million through 2009. In spite of the most recent agreement, on 25 September 2006 funding for the Court Challenges Program was eliminated. ${ }^{9}$

\section{Response to the Decision to Eliminate the Program}

As with the first cancellation, public response was swift. Soon after the September 2006 announcement, the Standing Committee on Canadian Heritage heard from twenty-two witnesses, eighteen of whom supported the reinstatement of the funding for the program. ${ }^{10}$ The committee tabled a report in February 2007 recommending continued funding for the CCP. In addition, Canada's Official Languages Commissioner, Graham Fraser, received 117 complaints between October 2006 and April 2007,, upon receipt of which he requested a moratorium on the cancellation. His request was denied. In his annual report tabled May 2007, the Commissioner openly criticized the Conservative government for cancelling the Court
Challenges Program, reminding the committee that it is "well known for having helped numerous individuals and groups pursue their rights in provincial and federal courts." 12 When the Commissioner appeared before a Senate committee in June 2007, he stated: "the elimination of the Court Challenges Program in particular delivered a serious blow to Canadians' ability to defend their language rights." ${ }^{33}$

Some have speculated that the cancellation of the program was an ideological decision, perhaps connected to the opposition of core supporters of the Harper government to same-sex marriage rights. "In some critical way," Professor Margot Young claims, "cancellation of this program is payback for the role it played in the successful legal struggle over same-sex marriage. One has only to look at a few of the websites or newsletters of groups on the religious right to see the linkage made between the attainment of same-sex marriage and the Court Challenges Program." 14

Others applauded the decision to cancel the program, suggesting that if the cause is significant enough, a group should be able to obtain its own funding to go to court rather than receive government assistance. Gwendolyn Landolt, national vice-president of REAL Women of Canada, ${ }^{15}$ claims: "If you have the support of the public, you can go to court, as we've done... simply because we've asked our members for the money and they've produced it...Why can't other groups do it?"16 Executive director of the Alberta-based Canadian Constitution Foundation $^{17}$ and critic of the CCP, John Carpay, adds to this sentiment: "I trust in the wisdom of Canadians and I trust in the compassion of Canadians to contribute to worthwhile court cases. Canadians know justice when they see it. What the Court Challenges Program is - or hopefully was - is an affront, a statement of disbelief and distrust in the wisdom and compassion of Canadians to give voluntarily to a just cause."18

The views of Ms. Landolt and Mr. Carpay may be defensible, but they are also easily refuted. Some disadvantaged groups simply do not have access to the funding needed to proceed to litigation when all other avenues of political influence have failed (these avenues will 
be discussed shortly). For example, it is unlikely that the members of the National Anti-Poverty Organization (NAPO) would be able to raise enough money to cover court costs from their members, let alone the cost of a solicitor.

One must also be careful in drawing a conclusion about the importance of a particular issue on the basis of the amount of financial support drawn from its community of supporters. This is a problematic assumption. To illustrate, while the situation in Vancouver's Downtown Eastside is a growing concern for all Canadians, local housing and poverty action groups do not attract substantial amounts of revenue from the public. Though the reasons for this are too varied and complex to discuss here, one certainly ought not assume that the shoestring budgets of these organizations are an indication that the public does not care about the plight of poor Canadians. It simply underlines the reality that not all groups and individuals are in a position to gather the funding needed to question government action or inaction.

\section{Why is the Court Challenges Program So Important?}

In essence, the failure of Canada's governments to provide the public with adequate opportunity to contribute to policy making and legislation has provided an important rationale for the Court Challenges Program as an alternative for groups and individuals seeking equal opportunity to influence decision makers and legislators. A brief examination of the efforts of Alberta's French-language official language minority groups and of provincial resistance to the public use of French, will help to clarify the importance of the program.

\section{Francophones in Alberta}

The 2001 census shows the majority of Canada's OLMGs live in Quebec, followed by Ontario, New Brunswick, and, perhaps surprising to some, Alberta. ${ }^{19}$ Indeed Franco-Albertans have been quietly contributing to the cultural landscape of the province for well over a century.

Edmund Aunger notes that Alberta has an "extensive body of language law buried in a century of statutory and regulatory provisions." ${ }^{20}$ While laws to protect the use of the French language in Alberta's public institutions do exist, the provincial government introduced legislative measures to promote English as the exclusive public language of the province. Nevertheless, these efforts did not prevent FrancoAlbertans from reminding the English-speaking majority in Alberta of their presence and their rights. An instructive example of the difficulty disadvantaged groups face in having their rights protected by the majority is the effort of an opposition member of Alberta's legislature to speak French in the Assembly in 1987. Known as "Laffaire Piquette," the Speaker refused to allow the member to use French in the legislature during question period, reinvigorating attention to the state of Canada's "other" official language in Alberta. Less than a year later, the Supreme Court of Canada ruled that official bilingualism, provided for in section 110 of the Northwest Territories Act, ${ }^{21}$ applied to the Legislative Assembly of Alberta, thus protecting the use of both French and English in the legislature and the courts. Further, the government was obliged to publish its statutes in both official languages.

Alberta's response to the Supreme Court's ruling was to enact the Languages Act $1988^{22}$ which states: "All Acts, Ordinances and regulations enacted before July 6, 1988 are declared valid notwithstanding that they were enacted, printed and published in English only." ${ }^{23}$ The Act essentially removes the government's obligation to have bills and legislative Standing Orders, records, and journals printed in French, but it still permits the use of French in oral communication in both the legislature and the courts. ${ }^{24}$ Enactment of the Languages Act exemplifies the unwillingness of the Alberta government to promote French in the province; thus, the survival of minority Francophone communities in Alberta, for example, may seem dependent on alternative means of redressing the government's lack of commitment to its legal obligations to its French-speakers.

The very cultural survival of many OLMG communities is dependent on the legislative cooperation of a province. As some provinces 
have been less than willing to support the needs and rights of these members of the electorate, many communities relied on the Court Challenges Program to help them challenge provincial legislation which they believe violates their right to live and prosper in the official language of their choice.

\section{Supplementing Public Access to the Policy Process}

Guy Matte, the most recent president of the Court Challenges Program notes: "[a] democratic system involves majority rule. We understand that, but defending minority rights is the reason why there has to be a charter to protect those rights from the whims of the majority. It's important to uphold these principles in Canada." ${ }^{25}$ In essence, the rights of all Canadians must be recognized to ensure legislation does not discriminate against disadvantaged groups. At the root of this discussion, then, is the importance of ensuring all citizens have sufficient opportunity to influence the policy process.

This concern with equitable influence over the policy process has indeed led Canadians to question the adequacy of our voting system, in addition to the adequacy of other features of our political framework. For example, the ability of citizens to influence policy making and legislation is clearly limited by Canada's "first past the post" (FPTP) electoral system which, combined with multiparty competition, ensures that national political parties can form governments with less than 50 percent of the popular vote. To secure and maintain public support, governing parties tend to focus on issues which appeal to a majority of voters, thus facilitating the neglect of some members of society. This creates periphery groups whose concerns are less likely to be observed by a party seeking majority support.

Nevertheless, academics have identified the bureaucracy, Members of Parliament, and cabinet ministers as "access points" in Canada's parliamentary system of government. Through these access points, it is suggested, all members of society are provided with an opportunity to advance their interests and concerns by contributing to the shaping of public policy and legislation. However, over the last several decades Canada has developed an increasingly centralized form of governance, and the level of control sought by prime ministers has diminished these access points. As a result, Canadians are forced to assert their Charter rights through court challenges. Since litigation is both timesensitive and expensive, only those with adequate resources are able to utilize the courts as a last resort.

\section{The Bureaucracy}

In his extensive research on pressure-group influence, Paul Pross has identified an ebb and flow to bureaucratic cooperation with interest groups. ${ }^{26}$ The Trudeau era, reflecting the emergence of social movements during this time, "ushered in the age of public consultation with the slogan 'come work with me." ${ }^{27}$ By contrast, the Mulroney period was one in which public access to the bureaucracy was more limited. Alexandra Dobrowolsky notes that as Mulroney dramatically reduced the bureaucracy, civil service "insiders" - once sympathetic to furthering the goals of the women's movement - began to fear retribution for talking with "special" interest groups. ${ }^{28}$ As one member of the bureaucracy put it: "Mulroney ran the government with favouritism and retribution and if you weren't a really big time supporter, then you were an enemy." ${ }^{29}$

While the concentration of power under Jean Chrétien has been well documented, ${ }^{30}$ Prime Minister Harper has gone even further to restrict the openness of the bureaucracy. In May 2007, for instance, Jeffrey Monaghan, an Environment Canada employee, was handcuffed in his office by the RCMP and taken away for questioning in regards to the leak of a document outlining Conservative plans to abandon the Kyoto Accord. ${ }^{31}$ The concern raised by critics at the time was that the handcuffs were being used as a scare tactic to keep rest of the bureaucracy in line.

\section{Members of Parliament}

If a group is able to persuade a Member of Parliament to raise a particular issue, there are two formal opportunities to introduce it into 
House of Commons proceedings: during question period or before parliamentary committee hearings. Since question period has become little more than a media spectacle, the larger part of any meaningful discussion in the House now takes place in parliamentary committee where strict party discipline does not always apply, and where the views of constituents can usually be expressed freely by MPs without interference or fear of repercussion. In 2002, when Stephen Harper was Leader of the Opposition, he co-authored a letter to the editor of the Globe and Mail stating: "Standing committees of the House should not simply be extensions of the Prime Minister's Office, and members of Parliament should choose their committee chairs by secret ballot and their own agenda, free from the Whip's direction." 32

Once in office, however, Harper indicated a change of mind regarding the importance of independent parliamentary committees to the policy process. For example, in May 2007, shortly after several meetings were shut down or corrupted by filibuster, a 200-page manual for Conservative committee chairs was leaked to Don Martin of the National Post, who revealed it to the public. Intended to guide the control of committees, the manual "details how to unleash chaos while chairing parliamentary committees." 33 Martin suggests that the manual "proves that the [committee] chairmen are under intense supervision from the powers above." 34 This view of the government was confirmed by Conservative House whip Jay Hill when he stated that committees "do not have the right to pick who the chair is ... [T] he chair, by the rules, must be a government member and I'm not going to allow the opposition to determine who that is." 35

\section{Cabinet Ministers}

Ministers of the Crown, particularly those in cabinet, have traditionally been considered the most effective and direct access point to influence public policy. As close advisors to the prime minister increasingly influence the policy process, ministers exercise less and less control over policy outputs. “The Prime Minister's Office and the Privy Council Office, in particular," Donald Savoie notes, "keep a watchful eye on ministers and departments. The centre of government, after all, now belongs to the prime minister, not to ministers." ${ }^{36}$ Unfortunately, this means that public access to policy influence via contact with ministers is stifled in favour of more centralized control over the policy process.

\section{Media}

Prime ministers increasingly rely on the media and professionalized advice to provide instant answers and partisan-strategic information via polling, media-reported public opinion, and professional marketing advice. In April 2007, acting on Prime Minister Harper's claim that "the press gallery has taken the view that they are going to be the opposition to the government," ${ }^{37}$ the Conservative government unveiled a 17,000 square foot, state-of-the-art media "war room" to provide instant-response capability for a pending election. Indeed, the Conservative government rigorously controls its image and messaging. Prime Minister Harper's turbulent relationship with the media may explain why, in August 2007, the PMO ordered that reporters be evicted from a hotel in Charlottetown where the Conservative caucus was holding its annual retreat. This change from the "freewheeling meetings" of the Tories when in opposition, Jane Taber and Gloria Galloway of the Globe and Mail note, is limiting the public's ability to interact with MPs: "In an effort to control the message, keep discipline and ensure that caucus members are all on the same page, access to MPs is being carefully controlled and monitored." 38

While it is true that the media provides a quick response to government policies, the government's efforts to control media messaging nevertheless renders the democratic process of public input and consultation on government policy and legislation relatively impotent. As a result, groups and individuals are forced to use the courts to participate in government by challenging policy and legislation created with everdiminishing public input. Since not all groups and individuals are similarly economically situated, groups and individuals have differing levels of access to the courts. Therefore, some members of society need assistance to access the courts as an alternative to traditional access 
points to policy influence. The Court Challenges Program helped groups that would otherwise be unable to access the policy process. In this sense, the program supplemented Canada's brokerage-style party system by including peripheral interests into the policy process via litigation, when access points failed to do so.

\section{If the Court Challenges Program Provides Assistance to Disadvantaged Canadians, Why is There So Much Opposition to It?}

Controversy has always surrounded the Court Challenges Program. Concerns have been raised regarding the administration of the program, the distribution of funding, and the selection of groups to fund for litigation support. Concerns related to democracy, to questions of minority rights protection at the expense of the majority, to conflicting definitions of equality, and to the delineation of what constitutes a "clarification" of Charter rights, are among the significant concerns raised.

Yet one must wonder why the Court Challenges Program, in particular, was eliminated while federal funds remain intact for other programs designed to assist with court and procedural costs. Deep conservative opposition to the Charter in general, and to "special" interest groups and socalled judicial activism in particular, may be at the root of the program's latest cancellation.

\section{The "Charter Revolution"}

Before 1982, the Supreme Court of Canada engaged in judicial review of the Constitution mainly to settle disputes over the division of powers. In Ted Morton \& Rainer Knopff's view, the introduction of the Charter facilitated a more activist Court, which has had a direct effect on the ability of Parliament to fulfill its obligations to the electorate. This so-called "Charter revolution," the argument goes, is supported by "special" interest groups which legitimize and encourage a political role for the courts. This in turn, effectively undermines the supremacy of Parliament, and as a result the wishes and needs of the majority are ignored if not undermined. ${ }^{39}$ As Morton \& Knopff put the point, since 1982 "judges have abandoned the [parliamentary] deference and self-restraint that characterized their pre-Charter jurisprudence and become more active in the political process." ${ }^{\prime 0}$

In his book Friends of the Court: the Privileging of Interest Group Litigants in Canada, Ian Brodie, one of the most vocal opponents of the Court Challenges Program and a former student of Morton's, contends that activist courts have been able to silence criticism by allying themselves with rights-seeking groups - including gay rights activists, feminists, and sympathetic lawyers and professors - which assist the courts in interpreting constitutional law, and use the Charter to create progressive policy. "The Supreme Court," Brodie claims, "is well on the road to establishing itself as a legislative, rather than a judicial, institution." ${ }^{11}$

From Brodie's perspective, the Court Challenges Program supports this process. "The federal government tried to encourage interest group litigation through the CCP," Brodie claims, "and there are good reasons to think that it was successful." ${ }^{\prime 2}$ He suggests that through outreach programs and litigation efforts, the program prompted many groups to utilize the courts to achieve their policy objectives. In so doing, the courts and their "friends" have taken over the role of legislators. Brodie observes: "The new judicial involvement in the policy process is sometimes a result of the state working through interest groups. The Court Challenges Program represents the embedded state at war with itself in court." ${ }^{\prime 3}$ It is indeed worth noting that in February 2006, seven months before the elimination of the Court Challenges Program, Ian Brodie was appointed Prime Minister Harper's Chief of Staff.

\section{Quelling the Revolution: Prime Minister Harper and the Anti-Court Party}

William Christian states: "Harper genuinely believes the sovereignty of Parliament has been eroded and that it is undesirable that an unelected court of nine men and women should have the final say over many fundamental aspects of Canadian life." ${ }^{\prime 4}$ If this is an accurate 
portrait of Harper's views of the judiciary, then the Conservative government's cancellation of the Court Challenges Program can be interpreted as an effort to stem government-supported litigation by "special" interest groups or "liberal" movements (such as the feminist or gay rights movement) that encourages the "activism" of the judiciary and the undermining of parliamentary supremacy. In this context, it should not be surprising that after cutting the program, the next step for Conservatives might perhaps be to focus efforts on the judicial interpreters of the Constitution.

Tasha Kheiriddin \& Adam Daifallah argue that "Canadian conservatives need to demand real reform of the judicial appointments process," ${ }^{35}$ and have advised them to heed the advice of the Vice-President of the National Citizens Coalition who has said that conservatives must "create a climate where there are more conservative voters, to elect more conservative politicians, and thus appoint more conservative judges. They must also produce more conservative lawyers who become those judges." 46 Prime Minister Harper has not kept his animosity towards the courts a secret, nor has he been shy about his intentions to stack the courts with judges who will reflect his own conservative views and agenda. By muffling the judicial component of the Charter revolution, Prime Minister Harper has taken steps - such as changing the configuration of federal Judicial Advisory Committees - to consolidate an ideologically conservative direction in the courts. He has begun to disenfranchise supporters of the Charter, and since it is virtually impossible to throw out the entrenched law of the Constitution, Harper will instead likely systematically unravel the efforts of Charter-supporters and their attempts to promote justice for all Canadians.

\section{Conclusion}

The litigation undertaken with the support of the Court Challenges Program illustrates that public input into policy making and legislation can be pursued in conjunction with representative democracy as it functions in a parliamentary system. The program supplements Canada's democratic process by recognizing and advanc- ing the rights of disadvantaged groups and individuals on the periphery of Canadian society.

The lens of the Charter revolution theory brings clarity to opposition to the program. Moreover, the removal of the financial support many "special" interest groups need to make use of what is perhaps the most effective tool available to achieve respect for minority rights - the courts - is further evidence of the tendency for power to be concentrated in the prime minister's office. As noted by Jeffery Simpson, Prime Minister Harper "centralizes everything through his office, giving ministers almost no margin for manoeuvre or initiative, tightly scripting every public event, controlling all messages to the public, running foreign policy by himself, and earning the reputation of a decisive but distant sun king of a leader." ${ }^{\text {"47 }}$ Ironically, Harper's centralizing tactics will continue to diminish traditional access points for public input in the policy process, exacerbating the need for disadvantaged groups to use the courts in a last attempt to contribute to policy and legislation.

While some have speculated that the elimination of the Court Challenges Program was linked to the issue of same-sex marriage, the Harper government's decision hurt many other groups as well. Members of Canada's multicultural society, persons with a disability, and OLMGs, to name a few, will also be less able to ensure public policy respects their rights as a result of the elimination of the program. As demonstrated in Alberta, for example, although there are constitutional guarantees for minority language protection, OLMGs cannot benefit from those protections without the cooperation of provincial governments willing to fully recognize them. When provinces fail to acknowledge minority language rights, the Court Challenges Program helped members of disadvantaged minority language groups hold provincial governments to constitutional guarantees which ensure they can live and prosper in the official language of their choice.

Though a concentration of power in the centre of government has been evolving over decades, the current government is the most extreme expression of its concentration in the PMO. As a result, most traditional public access 
points to the policy process have become ineffective. The increased use of a professionalized class of advisors has led to the exclusion of any "outside" input - including that of the prime minister's own cabinet not to mention MPs in the Conservative caucus - into the policy process. This development has forced many groups and individuals to rely on the courts as a last resort to influence public policy and ensure that their rights are protected. In this context, and not surprisingly, the Court Challenges Program was regarded as the proverbial thorn in the side of an increasingly centralized government not open to influence or criticism from the public. Unfortunately, as the program gave a voice to those who would otherwise have no opportunity to influence public policy, when the Harper government eliminated its funding, many of Canada's most disadvantaged groups were silenced.

\section{Notes}

* Larissa Kloegman, M.A., Department of Political Science, Dalhousie University, Halifax, Nova Scotia.

1 Part I of The Constitution Act, 1982, being Schedule B to the Canada Act 1982 (U.K.), 1982, c. 11 [Charter].

2 Treasury Board of Canada Secretariat, Press Release, "Canada's New Government cuts wasteful programs, refocuses spending on priorities, achieves major debt reduction as promised" (25 September 2006), online: Department of Finance $<$ http://www.tbs-sct.gc.ca/media/nrcp/2006/0925_e.asp $>$.

3 See: F.L. Morton \& Rainer Knopff, The Charter Revolution and the Court Party (Peterborough: Broadview Press, 2000).

4 (U.K.), 30 \& 31 Vict., c. 3, s. 91, reprinted in R.S.C. 1985, App. II, No. 5.

533 Vict., c. 3 (Can.).

6 The program also included sections 2 and 27 when used in support of equality arguments under Section 15.

7 It is important to note that when the program was expanded to include equality rights, challenges could only be made against federal legislation, rather than against both levels of government (as is permitted by language challenges). When asked about the discrepancy, Noel Badiou, executive director of the CCP said it was not clear, but was likely a political decision. Email correspondence [26 June 2007].
8 Ian Brodie, Friends of the Court: The Privileging of Interest Group Litigants in Canada (Albany: State University Press, 2002) at 109. When John Crosbie was questioned 20 years later (in 2005) about why a Conservative government would expand such a program, he replied: "It was political correctness. If we had discontinued the program we would have received very bad publicity. It would have led to the Liberal Party and opposition parties attacking on those grounds, saying we were not interested in human rights, and the institutions like The Globe and Mail, reinforcing our image as not being 'with it' on social issues. Because of that, I thought it was not worth it to quash the CCP when it was just beginning, in addition to which the Charter was new and needed to be tested to see what it really meant. But that time is long past." See Tasha Kheiriddin \& Adam Daifallah, Rescuing Canada's Right: Blueprint

for a Conservative Revolution (Mississauga: John Wiley \& Sons Canada Ltd., 2005) at 104.

9 Supra note 2.

10 House of Commons, Standing Committee on Canadian Heritage, Evidence, No. 027 (6 December, 2006), online: <http://cmte.parl. gc.ca/content/hoc/committee/391/chpc/evidence/ev2579520/chpcev27-e.pdf $>$; House of Commons, Standing Committee on Canadian Heritage, Evidence, No. 028 (11 December, 2006), online: <http://cmte.parl.gc.ca/content/hoc/ committee/391/chpc/evidence/ev2600142/chpcev28-e.pdf $>$; House of Commons, Standing Committee on Canadian Heritage, Evidence, No. 029 (13 December 2006), online: <http://cmte. parl.gc.ca/content/hoc/committee/391/chpc/evidence/ev2608871/chpcev29-e.pdf>; House of Commons, Standing Committee on Canadian Heritage, Evidence, No. 031 (1 February 2007), online: <http://cmte.parl.gc.ca/content/hoc/committee/391/chpc/evidence/ev2654968/chpcev31e.pdf $>$.

11 Bill Curry, "Legal aid decision provokes backlash" The Globe and Mail (9 May 2007).

12 Commissioner of Official Languages, Annual Report (Ottawa: Public Works and Government Services Canada, 2007) at 6.

13 Senate, Standing Senate Committee on Official Languages, Proceedings, No. 16 (4 June 2007), online: <http://www.parl.gc.ca/39/1/parlbus/commbus/senate/com-e/offi-e/pdf/16issue.pdf $>$.

14 Margot Young, "Justice on the block: Cutting federal money for the Court Challenges Program hardest on those most in need of their constitutional rights" Vancouver Sun (12 October 2006).

15 REAL Women of Canada is an anti-feminist, 
non-partisan, non-denominational organization of independent women. Its mandate is "Women's Rights but not at the expense of human rights." See: $<$ http://www.realwomenca.com $>$.

Standing Committee on Canadian Heritage, Evidence, No. 028 (11 December 2007), supra note 10 at 15.

17 The Canadian Constitution Foundation is a "registered charity, independent and non-partisan, with a unique charter which allows it to fund appropriate litigation." See: $<$ http://www. canadianconstitutionfoundation.ca $>$.

18 Supra note 16 at 15.

19 Achieved by taking the total OLMG population in the province as a percentage of the total OLMG population in Canada. Quebec accounted for 37.1 percent, while Ontario was 32.4 percent, New Brunswick 15.7 percent, followed by Alberta at 3.9 percent of the total OLMG population in Canada, and 9.2 percent of the entire population of the province. Statistics Canada, 2001 Census of Population: Population by Mother Tongue, by Province and Territory, E-STAT ed. (Ottawa: Statistics Canada, 2001), online: <http://estat. statcan.ca/>.

20 Edmund A. Aunger, "Legislating Language Use in Alberta: A Century of Incidental Provisions for a Fundamental Matter" (2004) 42 Alberta Law Rev. 463 at 497.

21 Northwest Territories Act, R.S.C. 1985, c. N-27.

22 Languages Act, R.S.A. 2000, c. L-6.

23 Ibid.

24 Kenneth Munro, "French Language and Educational Rights in Alberta: An Historical Perspective" in David Scheiderman, ed., Language and the State: The Law and Politics of Identity (Edmonton: Centre for Constitutional Studies, 1989) at 252 .

25 Standing Committee on Canadian Heritage, Evidence, No. 031 (1 February 2007), supra note 10 at 1.

26 Paul Pross, Group Politics and Public Policy, 2nd ed. (Toronto: Oxford University Press, 1992) at 48. Pross has traced the history of the bureaucracy, and consequently, the development and progression of the pressure group as well. While he does not presume that pressure groups had influence on the organization of the bureaucracy, he does contend that the state of the bureaucracy has a direct influence on the organization and effectiveness of pressure groups.

27 Paul Pross, "An Unruly Messenger: Interest Groups and Bureaucracy in Canadian Democracy" (Paper presented to the Annual Meeting of the Institute of Public Administration of Canada,
August 2006) [unpublished] at 6.

28 "Special" interest groups are considered by conservatives to be on the ideological left.

29 Alexandra Dobrowolsky "Of Special Interest: Interest, Identity, and Feminist Constitutional Activism in Canada" (1998) 31:4 Canadian J. of Political Science 707 at 732.

30 Donald Savoie, Governing from the Centre: The Concentration of Power in Canadian Politics (Toronto: University of Toronto Press, 1999); Jeffrey Simpson, The Friendly Dictatorship (Toronto: McClelland \& Stewart Ltd., 2001).

31 "Leak plugged? Federal worker arrested for allegedly leaking environment docs" Canadian Press (9 May 2007), online: Edmonton Sun $<$ http://www.edmontonsun.com/news/canada/2007/05/09/4166826.html>.

32 Bill Curry and Chuck Strahl, "Harper changes tune on appointments" The Globe and Mail (18 April 2006).

33 Don Martin, "Don Martin: Tories have book on political wrangling" The National Post (17 May 2007).

34 Ibid.

35 Murray Brewster, "Partisan political spat shuts down official languages committee" CBC News Online (15 May 2007).

36 Donald Savoie, "The Rise of Court Government in Canada" (1999) 32:4 Canadian J. of Political Science 635 at 643.

37 Alexander Panetta, "Harper says he'll avoid national media because they're biased against him" Canadian Press (24 May 2006).

38 Jane Taber and Gloria Galloway, "Journalists booted from Tory retreat" Globe and Mail (2 August 2007), online: The Globe and Mail $<$ http://www.theglobeandmail.com/servlet/story/ rtgam.20070802.wtories02/bnstory/national/ home $>$.

39 Supra note 3.

$40 \quad$ Ibid. at 14.

41 Supra note 8 at 124.

42 Ian Brodie, "Interest Group Litigation and the Embedded State: Canada's Court Challenges Program" (2001) 34:2 Canadian J. of Political Science 357 at 371.

43 Supra note 8 at 122.

44 William Christian, "Court-challenge staff had to know the axe would fall" Kitchener-Waterloo Record (30 September 2006).

45 Kheiriddin \& Daifallah, supra note 8 at 114.

$46 \quad$ Ibid.

47 Jeffery Simpson, "Canada goes greener: Farewell Kandahar, hello Kyoto" The Economist (December 2007) 47. 